\section{Are Number of Passes Related with Complications in Pediatric Native Kidney Biopsies?}

\author{
Pediatrik Nativ Böbrek Biyopsisinde Geçiş Sayısı \\ Komplikasyonla Illişkili midir?
}

\section{Mehmet Coşkun ๑ Şeyma Akkuş ๑ Şükran Keskin Gözmen ๑ Malik Ergin $\odot$ Erkin Serdaroğlu $\odot$ Nida Dinçel ๑}

\section{ABSTRACT}

Objective: The aim of this study was to determine the relationship between number of passes and complications in pediatric native kidney biopsies performed under ultrasonography guidance.

Methods: Forty-nine children who underwent native kidney biopsies using a 16 Gauge semi-automatic needle between 03/2019-03/2020 were included in the study. All patients were evaluated with ultrasonography before and after biopsy procedure to detect complication(s). Two or more passes were performed in most cases where electron microscopy was required. Requirement for transfusion or intervention was considered as a major complication. The technical success was calculated considering number of glomeruli harvested. Number of passes were compared with complication rates and number of glomeruli sampled. In statistical analysis, chi-square, $t$-test, and ANOVA tests were used.

Results: Minor, major complications and technical success rates were $36.7 \%, 0 \%$ and $100 \%$, respectively. Number of passes were 1 in 4, 2 in 30, 3 in 11 and 4 in 4 cases. Increasing number of passes were related with higher complication rates ( $p=0.002)$. The complication rates were $23.5 \%$, and $66.7 \%$ when $\leq 2$, and $\geq 3$ passes were used. Complication rate was higher when $\geq 3$ passes were used $(p=0.009)$, without any increase in the number of glomeruli sampled ( $p=0.839)$.

Conclusion: Pediatric native kidney biopsy was a safe procedure using 16 Gauge needle under ultrasonography guidance. Three of more passes caused an increase in minor complication rates without any increase in the number of glomeruli sampled.

Keywords: Pediatric renal biopsy, needle biopsy, bleeding, hematoma

Öz

Amaç: Bu çalışmanın amacı çocuk hasta grubunda ultrasonografi rehberliğinde gerçekleştirilen nativ böbrek biyopsilerinde geçiş sayısı ile komplikasyon ilişkisini saptamaktır.

Yöntem: 03/2019-03/2020 arasında US eşliğinde 16 Gauge yarı otomatik iğne ile nativ böbrek biyopsisi yapılan 49 çocuğu kapsamaktadır. Tüm olgular biyopsi öncesi ve sonrası ultrasonografi ile komplikasyon varlığı açısından tarandı. Elektron mikroskopisi gereken durumlarda veya ilk örneklemin yetersiz görüldüğü olgularda 2 veya daha fazla geçiş yapıldı. Transfüzyon veya girişim gerekliliği majör komplikasyon olarak belirlendi. Glomerül sayısına göre ișlemin teknik başarısı hesaplandı. Geçiş sayısı ile komplikasyon gelişimi ve glomerül sayısı birbiriyle karşılaştırıldı. Istatistiksel analizde, Ki-kare, $t$ ve ANOVA testlerinden faydalanıldı.

Bulgular: Minör, majör komplikasyon ve teknik başarı oranı sırasıyla \%36,7, \%0 ve \%100'dü. 4 olguda 1 kez, 30 olguda 2 kez, 11 olguda 3 kez ve 4 olguda 4 kez geçiş yapıldı; artan geçiş sayısı ile komplikasyon varlığı arasında anlamlı ilişki bulundu $(p=0,002)$. Geçiş sayısı $\leq 2$ ile $\geq 3$ karşılaştırıldığında: ilk grupta komplikasyon oranı \%23,5, diğerinde \%66,7 idi. Geçiş sayısı $\geq 3$ olanlarda $\leq 2$ 'ye kıyasla daha sık komplikasyon izlenirken ( $p=0,009)$, glomerül sayısı açısından fark yoktu $(p=0,839)$.

Sonuç: Çocuklarda, ultrasonografi altında 16 Gauge iğne ile nativ böbrek biyopsisi güvenlidir. Üç ve üzeri geçiş, glomerül sayısını artırmazken minör komplikasyonda artışa neden olur.

Anahtar kelimeler: Pediatrik renal biyopsi, iğne biyopsisi, kanama, hematom
Received: 16.08 .2020

Accepted: 23.09 .2020

Published Online: 30.04 .2021

Cite as: Coşkun M, Akkuş Ş, Keskin Gözmen Ş, Ergin $M$, Serdaroğlu E, Dinçel N. Are number of passes related with complications in pediatric native kidney biopsies?. İmir Dr. Behçet Uz Çocuk Hast. Dergisi. 2021;11(1):23-8.

Mehmet Coşkun

S.B.Ü. Dr. Behçet Uz Çocuk Hastalıkları ve Cerrahisi Eğitim ve Araştırma Hastanesi, Radyoloji Bölümü, İzmir, Türkiye

dr.mehmetcoskun@hotmail.com ORCID: 0000-0003-4339-898X

Ş. Akkuş 0000-0001-7371-0482 S.B.Ü. Dr. Behçet Uz Çocuk Hastalıkları ve Cerrahisi Eğitim ve Araştırma Hastanesi, Pediatri Kliniği, İmir, Türkiye

Ş. Keskin Gözmen 0000-0001-5052-1902 E. Serdaroğlu 0000-0002-6863-8866 N. Dinçel 0000-0002-1179-8519 S.B.Ü. Dr. Behçet Uz Çocuk Hastalıkları ve Cerrahisi Eğitim ve Araştırma Hastanesi, Pediatrik Nefrolojisi Kliniği, Izmir, Türkiye

M. Ergin 0000-0002-1927-9609 S.B.Ü. Dr. Behçet Uz Çocuk Hastalıkları ve Cerrahisi Eğitim ve Araştırma Hastanesi, Patoloji Bölümü, Izmir, Türkiye 


\section{INTRODUCTION}

Kidney biopsy is the gold standard in the diagnosis of parenchymal renal disease. Since it is an invasive procedure and carries the risk of complications, it is performed in a limited number of patients. Native kidney biopsy is indicated under following conditions: nephrotic syndrome, nephritic syndrome, proteinuria, suspicion of rapidly progressing glomerulonephritis, renal involvement of systemic diseases (such as systemic lupus erythematosus, Henoch-Schonlein purpura etc.), and treatment follow-up (1-3).

The blood flow to kidneys is one liter per minute ${ }^{(4)}$. Since kidney has high tissue blood supply per unit mass, kidney biopsy is prone to complications mostly hemorrhage. Therefore, renal biopsy is performed mostly under realtime ultrasound (US) guidance ${ }^{(5)}$. Complications can be minimized by preserving critical structures (such as ureter, renal artery and vein, renal pelvis etc.) and adequate sampling can be achieved with orienting the needle to the parenchyma under real-time US guidance ${ }^{(1)}$.

The British Pediatric Nephrology Association (BAPN) proposed standards for the kidney biopsy procedures in children. Accordingly, all patients should receive written information, $\leq 3$ passes should be achieved in $80 \%$ of cases, adequate tissue material for diagnosis should be obtained in $95 \%$ of cases, and rates of major complications defined as requirement for further investigation, intervention or monitoring should be less than five percent ${ }^{(6,7)}$.

In this study, the relationship between the number of passes and complications was investigated in pediatric US-guided native kidney biopsies using 16 Gauge (G) semi-automatic needles.

\section{MATERIAL and METHODS}

This retrospective study was approved by the institutional board and included 49 children who underwent native kidney biopsies using $16 \mathrm{G}$ semiautomatic needle under real-time US guidance between March 2019 and March 2020. The patients who did not give written consent, biopsies performed under non-US guidance or not using 16G biopsy needle (n:1) were excluded from the study. In all patients International
Normalization Ratio (INR) $<1.5$ and platelet counts > $100.000 / \mu \mathrm{L}$ were ensured before the procedure.

All patients were hospitalized for at least 1 day after biopsy. Hematocrit values were recorded before and 4 hours after the procedure and differences in hematocrit values were calculated. The patients who had hematoma thicker than $10 \mathrm{~mm}$ or whose hematocrit levels decreased 10 units were observed for at least 48 hours.

The procedure was performed with the patient in prone position and inferolateral poles of the left, and right kidneys were targeted in 39, and 10 cases, respectively. Sedation was achieved with intravenous midazolam (0.1 $\mathrm{ml} / \mathrm{kg}$ ) and lidocaine (2-4 $\mathrm{ml}$ ) was used as a local anesthetic. Native kidney biopsies were performed by an interventional radiologist and pediatric nephrologist in collaboration using a semi-automatic $16 \mathrm{G}$ biopsy needle $\left(\right.$ Geotek $^{\circledR}$, Ankara, Turkey) under real time US-guidance. The first sampling was done by a pediatric nephrologist, the following procedures by an interventional radiologist. US guidance was provided by an interventional radiologist. Multiple entries were performed in most cases requiring electron microscopy examination or inadequately sampled at the first pass.

Ultrasonographic examination was performed using a 6-9 $\mathrm{mHz}$ high-frequency linear probe (Aplio 500, Toshiba/ Canon $^{\circledR}$, Japan) by an interventional radiologist who sought for the presence of a complication 24 hours after the procedure. Hematoma requiring transfusion or intervention, injury to ureter, renal artery or vein, and death were considered as major complications.

Total number of glomeruli in the samples was noted by the pathologist. The adequacy of the sample for histopathological examination was determined based on the number of glomeruli sampled. Accordingly, sampling was suboptimal and nondiagnostic if $<10$ and $<5$ glomeruli were collected, respectively ${ }^{(8)}$. The cases were divided histopathologically into 7 subgroups: normal, nonspecific (minimal change disease or nephronophthisis), glomerulonephritis (GN), acute tubular necrosis (ATN), tubulointerstitial nephritis (TIN), IgA nephropathy, and focal segmental glomerulosclerosis (FSGS).

\section{Statistical analysis}

Statistical analysis was performed using SPSS version 20 (IBM $^{\circledast}$ Corp., Armonk, NY, USA). The relationship 
between gender, age, and complication was tested using Fisher exact and $t$ test, respectively. Differences in hematocrit values were compared with the presence of complication using t-test. Correlations between the number of passes and complication rates were evaluated using the chi-square test. Correlation between the number of passes and glomeruli sampled was evaluated using ANOVA test. The number of passes were grouped as $\leq 2$ and $\geq 3$. The groups were compared with complication rates using Fisher exact test and with number of glomeruli sampled using t-test. $\mathrm{P}<0.05$ was considered statistically significant.

\section{RESULTS}

The median age of 49 cases included in the study was 9 (standard deviation: \pm 4.6, range: 0.5-17) years. Our study population consisted of 29 boys and 20 girls . Histopathology results were as follows: 15 normal, 7 nonspecific, 12 GN, 3 ATN, 3 TIN, 8 IgA nephropathy, and 1 FSGS.

Minor complications were seen in 18 (36.7\%) cases. No major complication was observed. The thickest hematoma was $22 \mathrm{~mm}$ in diameter. Four cases with hematoma thicker than $10 \mathrm{~mm}$ were followed and no additional treatment was needed (Figure 1). The longest hospitalization was 3 days. There was no complication other than hematoma.

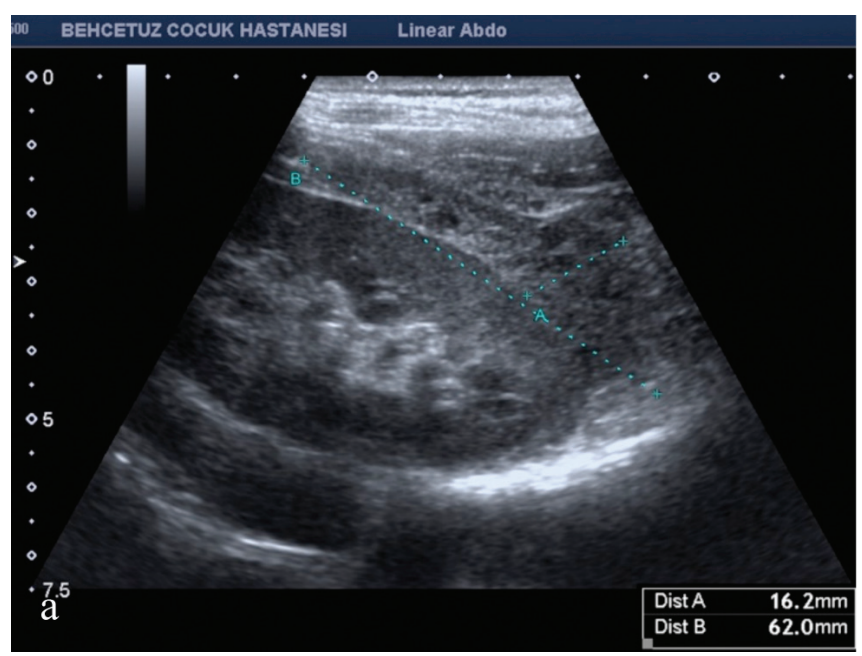

Figure 1. A 13-year-old boy who underwent renal biopsy with three passes. a) A $16 \times 62 \mathrm{~mm}$ subcapsular hematoma was observed at the $24^{\text {th }}$ hour US examination. b) The hematoma size was reduced to $10 \times 59 \mathrm{~mm}$ and he was discharged at the third day. Hematocrit was $41.2 \%, 40.2 \%$, and $38.9 \%$ before, four hours, and three days after the procedure, respectively. 
$\%$ technical success rate. Median number of $32( \pm 20$, 8-100) glomeruli were harvested. Sampling was optimal in all except one case where only 8 glomeruli were collected. Median number of 40,37, 38, and 30 glomeruli were sampled with one, two, three, and four passes, respectively. There was no relation between the number of passes and the number of glomeruli sampled $(p=0.913)$.

The complication rates were $23.5 \%$, and $66.7 \%$ when $\leq 2$, and $\geq 3$ passes were performed. Complications were more frequently encountered when $\geq 3$ passes were used $(p=0.009)$. Number of glomeruli sampled were not different between these groups $(p=0.839)$.

\section{DISCUSSION}

This study examined pediatric native kidney biopsies performed with $16 \mathrm{G}$ semi-automatic needle. Minor hematoma was seen in $36.7 \%$ of the cases without any major complication. Adequate sampling was achieved in all. Using 3 or more passes raised minor complication rates without increasing the number of glomeruli collected. These results supported the proposal of BAPN standard as, "The number of passes should be $\leq 3$ in $80 \%$ of cases" (7).

Usage of automatic needle under real-time US guidance has facilitated the procedure ${ }^{(9)}$. In a study including 533 children, minor hematoma was less common, and the hospital stay was shorter when biopsies were performed under real-time US guidance ${ }^{(10)}$. In a metaanalysis, it was reported that real-time US guidance did not change the rates of minor or major complications in children ${ }^{(11)}$. However, in plenty of studies opposing outcomes have been reported $(10,12,13)$. Using automatic needles greater number of glomeruli have been harvested with lower complication rates relative to former handdriven system ${ }^{(14,15)}$. In this study, semi-automatic needles under US guidance were used in all cases. We argued that under real-time US guidance adequate tissue sampling can be achieved, and semi-automatic needles with traceable distal needle tip are safer and reduce complication rates.

Hematoma was the most common complication seen after biopsy ${ }^{(2)}$. Post-biopsy bleeding rates ranged between $4 \%$ and $44 \%$ in the literature ${ }^{(12,13,16-19)}$. In a study by Ding et al. ${ }^{(18)}$ including 183 children, minor, major complications, and technical success rates were $12.9 \%, 3 \%$ and $98 \%$, respectively. Printza et al. (12) reported that, the corresponding rates were $11 \%, 0 \%$, and $97.7 \%$, respectively. In the meta-analysis of Varnel et al. ${ }^{(11)}$ minor complication was seen in $18 \%$ whereas transfusion and intervention were required in $0.9 \%$, and $0.7 \%$ of the cases, respectively. Major hemorrhage requiring transfusion or intervention were seen in $3 \%$ of the adults, and $1.9 \%$ of the children in the Norwegian Kidney Registry data including 9288 cases. Besides, it was emphasized that major hemorrhage was more common in the centers performing less than 30 biopsies per year ${ }^{(19)}$. In our study, minor, major complications, and technical success rates were $36.7 \%$, $0 \%$, and $100 \%$, respectively. Our minor bleeding rate was relatively higher compared to the literature which may be related to the use of high frequency linear probe . Linear probe provides higher resolution with increased detectability of small hematomas, such that the thickness of the subcapsular hematoma was less than $10 \mathrm{~mm}$ in 14 of 18 attempts $(77.8 \%)$.

The caliber of the biopsy needle was correlated with complication and technical success rates. In renal biopsy usually 14,16 , and $18 \mathrm{G}$ needles have been used ${ }^{(2)}$. The diameters of these biopsy needles are 1000, 700, and 350 $\mu \mathrm{m}$, respectively. An $18 \mathrm{G}$ needle may cause glomerular fragmentation or undersampling since the glomeruli can be as small as $250 \mu \mathrm{m}$ in diameter ${ }^{(1)}$. In a study comparing 14 and $16 \mathrm{G}$ automatic needles, the number of glomeruli sampled did not differ, while perirenal hematoma was more frequently seen when $14 \mathrm{G}$ biopsy needles were used ${ }^{(20)}$. In the study of Roth et al. ${ }^{(21)}$ comparing 16 and $18 \mathrm{G}$ needles, complication rates were similar while greater number of glomeruli were harvested using $16 \mathrm{G}$ needles. Sinha et al. ${ }^{(9)}$ reported that the median number of 25 , and 13 glomeruli were sampled when 16 , and $18 \mathrm{G}$ biopsy needles were used, respectively. It was emphasized that using $16 \mathrm{G}$ biopsy needles was advantageous in sampling greater number of glomeruli without any increase in complication rates. In our study, all cases were sampled using standard $16 \mathrm{G}$ semi-automatic needles and adequate sampling was achieved in all with a median of 32 glomeruli collected.

In a study by Korbet et al. ${ }^{(14)}$ any significant relation between the number of passes and the presence of hematoma could not be found. Minor hematoma was 
seen in $13.5 \%$ of the cases when $\leq 2$ passes and in $18.5 \%$ of them when $\geq 3$ passes were used. However, this study was performed with adult patients. Nevertheless, the National Kidney Foundation recommended less than 5 passes due to the increased risk of bleeding ${ }^{(1)}$. British Pediatric Nephrology Association proposed that $\leq 3$ passes should be achieved in $80 \%$ of occasions ${ }^{(6,7)}$. In this study, minor hematoma was more frequent in the pediatric native kidney biopsies performed with $\geq 3$ passes without any increase in the number of glomeruli harvested.

The factors such as surgeon's experience, systolic high blood pressure, low hemoglobin level, and renal failure were also associated with development of complications $(2,14,18,19,22)$.

This study had several limitations. First, possible risk of selection bias exists due to its retrospective design. Second, the patient population was small. Third, the procedure was performed by two different surgeons. The experience of surgeons was different and had a potential of affecting the complications albeit increased generalizability of the results. Fourth, the biopsy procedure and US examination to detect presence of any complication were performed by the same interventional radiologist which carried risk of bias. US images were recorded in archives to prevent this limitation.

In conclusion, pediatric native kidney biopsy is safe under real-time US guidance using a $16 \mathrm{G}$ semi-automatic needle, and $\geq 3$ passes increase the risk of minor hematoma without any increase in the number of glomeruli sampled. Two passes may be convenient for adequate sampling.

Ethics Committee Approval: S.B.Ü. Izmir Dr. Behçet Uz Pediatric Diseases and Surgery Training and Research Hospital Ethics Committee approval was obtained (03.07.2020/799).

Conflict of Interest: Nothing to disclosure.

Funding: Used no funding resource. Informed Consent: Obtained.

\section{REFERENCES}

1. Luciano RL, Moeckel GW. Update on the Native Kidney Biopsy: Core Curriculum 2019. Am J Kidney Dis. 2019;73(3):404-15.

https://doi.org/10.1053/j.ajkd.2018.10.011

2. Hogan JJ, Mocanu M, Berns JS. The Native Kidney Biopsy: Update and Evidence for Best Practice. Clin J Am Soc
Nephrol. 2016;11(2):354-62. https://doi.org/10.2215/CJN.05750515

3. Avner ED, Harmon WE, Niaudet P, Yoshikawa N, Emma F, Goldstein SL. Pediatric Nephrology. $7^{\text {th }}$ ed. Berlin: SpringerVerlag Berlin Heidelberg; 2016. https://doi.org/10.1007/978-3-662-43596-0

4. Dalal R BZ, Sehdev JS. Physiology, Renal Blood Flow and Filtration. [Updated 2019 May 15]. In: StatPearls [Internet]. Treasure Island (FL): StatPearls Publishing; 2020 Jan-. Available from: https://www.ncbi.nlm.nih.gov/books/ NBK482248/.

5. Lees JS, McQuarrie EP, Mackinnon B. Renal biopsy: it is time for pragmatism and consensus. Clin Kidney J. 2018;11(5):605-9.

https://doi.org/10.1093/ckj/sfy075

6. Hussain F, Mallik M, Marks SD, Watson AR. Renal biopsies in children: current practice and audit of outcomes. Nephrol Dial Transplant. 2010;25(2):485-9.

https://doi.org/10.1093/ndt/gfp434

7. Nephrology BAP. BAPN Sub-Committee for Clinical Standards and Guidelines 2012 [Available from: https://renal.org/ wp-content/uploads/2017/07/renal-biopsy-standardsstatement.pdf.

8. Nammalwar BR, Vijayakumar M, Prahlad N. Experience of renal biopsy in children with nephrotic syndrome. Pediatr Nephrol. 2006;21(2):286-8.

https://doi.org/10.1007/s00467-005-2084-5

9. Sinha R, Maji B, Sarkar B, Meur S. A prospective audit of complications in 100 consecutive pediatric percutaneous renal biopsies done under real-time ultrasound guidance. Indian J Nephrol. 2016;26(5):329-34. https://doi.org/10.4103/0971-4065.171232

10. Hayatghaibi SE, Ashton DJ, Orth RC. Pediatric percutaneous renal biopsies: comparison of complications between realtime ultrasound guidance and pre-procedure ultrasoundaided skin-marking techniques. Pediatr Radiol. 2019;49(5):626-31. https://doi.org/10.1007/s00247-018-4321-7

11. Varnell CD, Jr., Stone HK, Welge JA. Bleeding Complications after Pediatric Kidney Biopsy: A Systematic Review and Meta-Analysis. Clin J Am Soc Nephrol. 2019;14(1):57-65. https://doi.org/10.2215/CJN.05890518

12. Printza N, Bosdou J, Pantzaki A, Badouraki M, Kollios K, Ghogha $C$, et al. Percutaneous ultrasound-guided renal biopsy in children: a single centre experience. Hippokratia. 2011;15(3):258-61.

13. Franke M, Kramarczyk A, Taylan C, Maintz D, Hoppe B, Koerber F. Ultrasound-guided percutaneous renal biopsy in 295 children and adolescents: role of ultrasound and analysis of complications. PLoS One. 2014;9(12):e114737. https://doi.org/10.1371/journal.pone.0114737

14. Korbet SM, Volpini KC, Whittier WL. Percutaneous renal biopsy of native kidneys: a single-center experience of 1,055 biopsies. Am J Nephrol. 2014;39(2):153-62. https://doi.org/10.1159/000358334

15. Doyle AJ, Gregory MC, Terreros DA. Percutaneous native renal biopsy: comparison of a 1.2-mm spring-driven system with a traditional 2-mm hand-driven system. Am J Kidney Dis. 1994;23(4):498-503. https://doi.org/10.1016/S0272-6386(12)80370-2

16. Simckes AM, Blowey DL, Gyves KM, Alon US. Success and safety of same-day kidney biopsy in children and adolescents. Pediatr Nephrol. 2000;14(10-11):946-52. https://doi.org/10.1007/s004670000316 
17. Rianthavorn P, Kerr SJ, Chiengthong K. Safety of paediatric percutaneous native kidney biopsy and factors predicting bleeding complications. Nephrology (Carlton). 2014;19(3):143-8.

https://doi.org/10.1111/nep.12184

18. Ding JJ, Lin SH, Huang JL, Wu TW, Hsia SH, Lin JJ, et al. Risk factors for complications of percutaneous ultrasound-guided renal biopsy in children. Pediatr Nephrol. 2020;35(2):271-8. https://doi.org/10.1007/s00467-019-04367-8

19. Tøndel C, Vikse BE, Bostad L, Svarstad E. Safety and complications of percutaneous kidney biopsies in 715 children and 8573 adults in Norway 1988-2010. Clin J Am Soc Nephrol. 2012;7(10):1591-7.

https://doi.org/10.2215/CJN.02150212
20. Chunduri S, Whittier WL, Korbet SM. Adequacy and complication rates with 14- vs. 16-gauge automated needles in percutaneous renal biopsy of native kidneys. Semin Dial. 2015;28(2):E11-4. https://doi.org/10.1111/sdi.12332

21. Roth R, Parikh S, Makey D, Foster J, Rozenblit G, Satoskar A, et al. When size matters: diagnostic value of kidney biopsy according to the gauge of the biopsy needle. Am J Nephrol. 2013;37(3):249-54.

https://doi.org/10.1159/000347219

22. Corapi KM, Chen JL, Balk EM, Gordon CE. Bleeding complications of native kidney biopsy: a systematic review and meta-analysis. Am J Kidney Dis. 2012;60(1):62-73. https://doi.org/10.1053/j.ajkd.2012.02.330 